Original Paper http://ajol.info/index.php/ijbcs http://indexmedicus.afro.who.int

\title{
Effects of Jatropha curcas L. (Euphorbiaceae) composts on biochemical, phytochemical and nutraceutical quality of sorghum (Sorghum bicolor (L.) Moench) seeds
}

\author{
Abdoul-Nassiré DERRA ${ }^{1 *}$, Barthelemy YÉLÉMOU ${ }^{2}$, Hemayoro SAMA $^{1}$ and \\ Adama HILOU ${ }^{1}$ \\ ${ }^{1}$ Laboratory of Biochemistry and Applied Chemistry (LABIOCA), University Joseph KI-ZERBO 01 BP 7021 \\ Ouagadougou, Burkina Faso. \\ ${ }^{2}$ Institute of Environment and Agricultural Research (INERA), Department of Natural Resources Management \\ and Production System, INERA-Saria BP 10 Koudougou Burkina Faso. \\ ${ }^{*}$ Corresponding author; E-mail: der_abdelnasser@yahoo.fr, Phone: +22670850595
}

\begin{tabular}{ccc}
\hline Received: 13-06-2021 & Accepted: 25-08-2021 & Published: 30-10-2021 \\
\hline
\end{tabular}

\begin{abstract}
A study on the potential for agronomic valorisation of Jatropha curcas co-products in rainfed agriculture was conducted in Burkina Faso to determine the impacts of compost-based by-products of Jatropha on the nutritional quality of the sorghum seeds produced. The effect of 13 composts was evaluated and compared to a control. Sorghum seed parameters determined were total phenolics, total flavonoids, starch, total sugars, phorbol esters and antioxidant activities measured with DPPH and FRAP protocols. The results have showed a statistically significant difference between the treatments for all parameters. Correlations between the different parameters mean a simultaneous improving of biochemical parameters of sorghum. The ferric reduction ability power was significantly and positively correlated to total phenolics $(\mathrm{r}=0.792)$ and flavonoids $(\mathrm{r}=0.602)$ content. The analysis of the main components has enabled the various treatments to be divided into 4 groups. Flavonoid content and FRAP activity are closely related to the treatment BM+CP. The treatments for the control group have improved total polyphenol content and DDPH activity. The others groups have improved starch and carbohydrate content. The phorbol ester dosage revealed no contamination of sorghum seeds. These results suggest that Jatropha by-products compost can be used as an alternative or complement to chemical fertilizers for soil fertility improvement.
\end{abstract}

(C) 2021 International Formulae Group. All rights reserved.

Keywords: Jatropha curcas, composts, biofertilizer, Sorghum bicolr, nutraceutical quality, phytotoxins.

\section{INTRODUCTION}

In recent decades, developing countries have significantly experienced increased their energy needs for industrial production, transportation and comfort (Cao et al., 2016). Fossil fuels such as mineralized carbon are unsustainable because they are exhaustible and above all their combustion produces waste that is toxic to the biosphere. Greenhouse gas emissions and other harmful gases are responsible for pollution and climate change (Asif and Muneer, 2007). The current climate 
variability makes developing countries vulnerable to extreme weather events, resulting in considerable economic damage (Mirza, 2003). In Burkina Faso, apart from the ecological question, fossil energy is imported and in recent years the gradual inflation in prices has added further burden on the economy. It has therefore become imperative to find alternative sources of energy (Hanff et al., 2011). In Burkina Faso, oils and biodiesel derived from Jatropha curcas have been considered as the best alternative to fossil fuel to reduce $\mathrm{CO}_{2}$ emissions and provide accessible energy to the most vulnerable populations (Janin and Ouédraogo, 2009). Although Jatropha curcas is not very demanding in terms of soil fertility, its development requires good management in order to avoid the competition for soils between food production and energy production (Firdaus and Husni, 2012). Numerous studies have reported that the species does not create competition in the use of food as fuel because it is grown in a combination of food crops in a corridor without harmful competition with cereal crops (Bazongo et al., 2015). However, Jatropha curcas has always been known for its phytoxicity to animals; this has therefore raised the question of the possible phytotoxicity of its biomass (residual or composted) compared to neighbouring cereal plants.

In sub-Saharan Africa, crop yields are limited by many factors, one of which is nutrient deficiencies. Soils may have inherently low levels of nutrients because of low soil organic matter levels and the limited use of nutrient inputs by farmers (Bationo et al., 2007). Nitrogen $(\mathrm{N})$ and phosphorous $(\mathrm{P})$ deficiencies are the main soil fertility constraints in most of the soils of West Africa (Ouédraogo et al., 2001; Shuaibu et al., 2018). In addition, the degradation of these soils following natural phenomena (water and/or wind erosion) and/or anthropogenic phenomena contribute greatly to impoverish them more, thus affecting their productivity. More than $24 \%$ of cultivable soils suffer this phenomenon (Somda et al., 2017). To intensify agriculture and improve crop yield use of mineral fertilizers has to be increased. Mineral fertilizers on the other hand are generally costly and unavailable to the small-scale farmers. The mineral fertilizers even when available could have negative impact on the environment if not properly used; even as most of the farmers do not know how to use them for optimum production (Joshi et al., 2014). To remedy this, different management methods are adopted among them organic fertilizers.

Organic fertilizers improve soil physical and chemical properties by improving the stability of soil aggregates, reducing the risk of erosion, increasing soil porosity and water holding capacity and decreasing soil acidification which is important for plant growth (Ouédraogo et al., 2001; N'Dayegamiye et al., 2005). Addition of organic materials of various origin to soil is one of the most common strategies to improve soil physical properties and the use of compost on crops have been reported to improve crop yield and quality and play a key role in the maintenance of soil productivity (Shuaibu et al., 2018). Crop growth, yield and product quality in relation to application of different organic fertilizers have been widely reported. However, the production of organic fertilizers is limited by decrease in primary biomass production which restricts the burden of ruminants and the possibility of produce compost (Traore et al., 2015). Faced with this situation, the exploration of new sources of fertilizers mainly based on by-products from agriculture that cannot be used for other purposes could be a solution to improve soil fertility at a lower cost in Sudanian-Sahelian Africa. Among agricultural by-products, those of Jatropha curcas are of particular interest because, in addition to being available, their toxicity makes them unsuitable for consumption by livestock (Sama et al., 2018). Its leaves, stems, fruit hull and seed oil cake are used as potential fertilizer (Derra et al., 2013). Also, the different effects of these organic fertilisers on the quality of cereals, especially sorghum, are to be informed. Jatropha curcas contains many molecules, including phorbol esters which are known to be toxic to humans and animals. It is therefore necessary to 
confirm the non-contamination of crops produced from Jatropha compost (Das and Chandran, 2011).

Sorghum (Sorghum bicolor (L.) Moench) is a tropical plant belonging to the family of Poaceae and it is the fifth most important cereal crop in the world and the dietary staple of more than 500 million people in more than 30 countries (Kenga et al., 2004). Besides being a staple food for human, it serves as an important source of feed and fodder for animals particularly in semi-arid regions (Akinseye et al., 2017). The objective of this study is to generate through the evaluation of the impact of various compost-based Jatropha curcas by-products on the chemical composition and antioxidant activities of sorghum grains data to prove or otherwise the hypothesis of potential soil or cereal poisoning by phytotoxins.

\section{MATERIALS AND METHODS}

\section{Experimentation, test plant and treatments Presentation of the site and the experimental field}

The study was carried out during 2017 crop year at the experimental site of the agricultural research station of Saria $\left(12^{\circ} 16^{\prime} \mathrm{N}\right.$ and $2^{\circ} 9^{\prime} \mathrm{W}$ ) located $25 \mathrm{~km}$ east of Koudougou (Burkina Faso). It is a Sudano-Sahelian region with an average annual rainfall of $800 \mathrm{~mm}$ from May to October with large inter- and intra-annual fluctuations. The average temperature is about $30^{\circ} \mathrm{C}$ per year. Relative humidity is less than $20 \%$ in the dry season and exceeds $60 \%$ in the rainy season.

The experimental field consists of 4 blocks comprising 14 units plots (13 treatments +1 control) per block, arranged on an area of $2519.2 \mathrm{~m}^{2}$. The elementary plots are $5.20 \mathrm{~m}$ by $4 \mathrm{~m}$. The treatments are spaced $1 \mathrm{~m}$ apart and the repetitions separated by $2 \mathrm{~m}$. For each treatment, a dose of $5 \mathrm{t} / \mathrm{ha}$ corresponding to $10.4 \mathrm{~kg}$ of compost was applied to each unit plot at the beginning of the campaign, except in the control plot. A control plot was considered in each block. After spreading the various substrates (composts), a plowing is done with cows at $15-20 \mathrm{~cm}$ deep. An extended dose of
NPK is given 15 days after sowing and urea 30 days after weeding.

\section{Plant material and treatments}

The culture system set up corresponds to a monoculture of sorghum (Sorghum bicolor, variety ICSV 1049). Sorghum was grown on plots treated with various composts in order to compare the effect of these composts on the nutritional quality of the seeds produced. A total of 14 treatments including one control and 13 treatments with Jatropha composts was considered. At the end of the crop year, seeds from each treatment were collected and used as samples for the various analyses. The treatments are presented in Table 1.

Evaluation of chemical compounds and antioxidant activities

Determination of total phenolic and total flavonoid contents

A mass of $500 \mathrm{mg}$ of sorghum seeds powder were extracted with $10 \mathrm{~mL}$ of ethanol/water $(80: 20 \mathrm{v} / \mathrm{v})$. The mixture was shaken for $24 \mathrm{~h}$ and centrifuged at $4500 \mathrm{rpm}$ for 15 minutes. The supernatant was used for the quantification of total phenolics and total flavonoids contents. The total phenolics and total flavonoids contents were determined respectively at $760 \mathrm{~nm}$ and $415 \mathrm{~nm}$. The total phenolics were expressed as $\mu \mathrm{g}$ of gallic acid equivalent per $\mathrm{mg}$ of seeds ( $\mu \mathrm{g} \mathrm{GAE} / \mathrm{mg}$ of seeds) and total flavonoids expressed as $\mu \mathrm{g}$ of quercetin equivalents per $\mathrm{mg}$ of seeds ( $\mu \mathrm{g}$ $\mathrm{QE} / \mathrm{mg}$ of seeds) (Sama et al., 2018).

\section{Estimation of carbohydrates content}

A mass of $500 \mathrm{mg}$ of sorghum seed powder was homogenized in $5 \mathrm{~mL}$ of $80 \%$ hot ethanol. The homogenate was centrifuged at $4500 \mathrm{rpm}$ for $10 \mathrm{~min}$ after cooling. The supernatant was used to estimate the carbohydrate content of seeds at $490 \mathrm{~nm}$ using the phenol-sulfuric acid method. The total sugars content was expressed as $\mu \mathrm{g}$ glucose equivalent per gram of seeds weight $(\mu \mathrm{g}$ GE/mg of seeds) (Dubois et al., 1956).

\section{Estimation of starch content}

A mass of $100 \mathrm{mg}$ of sorghum powder was homogenized with $5 \mathrm{~mL} \mathrm{KOH}, 1 \mathrm{~N}$ room temperature and then neutralized with $5 \mathrm{~mL}$ 
$\mathrm{HCl}, 1 \mathrm{~N}$ and boiled in a water bath for $15 \mathrm{~min}$ then readjusted to $10 \mathrm{~mL}$. After cooling in a water bath at $25^{\circ} \mathrm{C}$ for 15 minutes, the mixture was centrifuged and supernatant collected. 125 $\mu \mathrm{L}$ of extract (supernatant) was mixed with an equal volume of reagent $I_{2} / \mathrm{KI}$ and the absorbance read at $580 \mathrm{~nm}$. The starch content of the seeds is determined using a reference curve made with starch $(0-2.5 \mathrm{mg} / \mathrm{mL}$ ) (Jarvis and Walker, 1993).

\section{Determination of phorbol esters content}

The phorbol esters in sorghum seeds was determined by the HPLC method (Makkar et al., 1997). The sample was extracted with methanol followed by centrifugation. The separation at room temperature $\left(22^{\circ} \mathrm{C}\right)$, with an analytical column C18 $(250 \times 4 \mathrm{~mm})$, at the same flow rate of $1.3 \mathrm{~mL} / \mathrm{min}$ using an elution gradient composed of three solvents: (A) Ophosphoric acid (85\%), (B) acetonitrile and (C) tetrahydrofuran. Peaks of phorbol esters are detected at $280 \mathrm{~nm}$. The results were expressed as phorbol-12-myristate 13-acetate.

\section{Evaluation of antioxidant activity}

A mass of $500 \mathrm{mg}$ of sorghum seeds powder was extracted with $10 \mathrm{~mL}$ of ethanol/water $(80: 20 \mathrm{v} / \mathrm{v})$. The mixture was shaken for $24 \mathrm{~h}$ and centrifuged at $4500 \mathrm{rpm}$ for 15 minutes. The supernatant was used to estimate the antioxidant activities (Sombié et al., 2019).

- Ferric reducing antioxidant power (FRAP) assay: The ability of sorghum seeds extracts to reduce iron (III) to iron (II) was measured at $700 \mathrm{~nm}$ using the method described by Sombié et al. (2011). Iron (III) reducing activity was expressed in $\mu \mathrm{g}$ of ascorbic acid equivalents per gram of seeds ( $\mu \mathrm{g} \mathrm{AAE} / \mathrm{mg}$ of seeds).

- DPPH (2,2-diphenyl-1-picrylhydrazyl) radical scavenging activity : The ability of sorghum seeds extracts to scavenge the DPPH radical was evaluated at $517 \mathrm{~nm}$ as described by (Sombié et al., 2011). The means of three values were expressed as $\mu \mathrm{g}$ of ascorbic acid equivalents per gram of seeds ( $\mu \mathrm{g} \mathrm{AAE} / \mathrm{mg}$ of seeds).

\section{Statistical analyses}

All experiments were repeated three times with four replicates per treatment for sorghum seeds production. The data collected by MS Excel software were subjected to analysis of variance (ANOVA) using XL-Stat 2016 software. The Newman-Keuls multiple rank test at the 5\% threshold was used to separate the means.

Table 1: List of applicated treatments.

\begin{tabular}{ll}
\hline Codes & \multicolumn{1}{c}{ Treatments } \\
\hline G_S & Jatropha pod alone \\
G+CP & Jatropha pod + Compost plus \\
G+BV & Jatropha pod + Cow dung \\
T_S & Jatropha cake alone \\
T+CP & Jatropha cake + Compost plus \\
T+BV & Jatropha cake + Crow dung \\
P+CP & Straw of sorghum + Compost plus \\
P_S & Straw of sorghum alone \\
G+DA & Jatropha pod + Slaughterhouse waste \\
T+DA & Jatropha Cake + Slaughterhouse waste \\
BM_S & Biomass of Jatropha alone \\
BM+CP & Biomass of Jatropha + Compost plus \\
BM+BV & Biomass of Jatropha + Cow dung \\
Control & No compost added \\
\hline
\end{tabular}




\section{RESULTS \\ Carbohydrates and starch contents of sorghum seeds}

The results revealed significant variation between control and all treatments (Figure 1). The different contents are ranged from $0.18 \pm 0.02$ to $3.10 \pm 0.22 \mu \mathrm{g} \mathrm{GE} / \mathrm{mg}$ dry weight of seed powder. The highest value was recorded at the treatment $\mathrm{T} \_\mathrm{S}$ while the lowest was recorded at the treatment $\mathrm{P}+\mathrm{CP}$. In addition, treatment $\mathrm{T} \_\mathrm{S}, \mathrm{T}+\mathrm{CP}, \mathrm{T}+\mathrm{DA}, \mathrm{T}+\mathrm{BV}$, $\mathrm{G}+\mathrm{DA}$ and $\mathrm{BM}+\mathrm{BV}$ presented highest content compared to the control. The treatment P_S was not significantly different from the control. The other treatments presented lowest values compared to the control.

The results show a significant variation in seed starch content according to the treatments (Figure 2). In addition, the treatment P_S had the highest value while the treatment $\mathrm{BM}+\mathrm{CP}$ had the lowest. The treatments $\mathrm{G}+\mathrm{BV}$, T_S, T+DA, BM_S and BM+CP presented lowest contents and $\mathrm{P}+\mathrm{CP}$ presented no significant difference compared to the control. The others all treatments improved starch content compared to the control.

\section{Phorbol esters contents of sorghum seeds}

The presence of phorbol ester determines whether the sorghum could be consumed by humans or not. The Figure 3 shows the chromatograms of the samples analysed. Peaks of phorbol esters (three types) appear under between 26 and 31 minutes and are detected at $280 \mathrm{~nm}$. The results were expressed as phorbol-12-myristate 13-acetate (appearing between 34 and 36 minutes). Qualitative identification of phorbol esters in sorghum seeds and in the different compost treatments (Table 2) reveal that phorbol esters are absent in all the samples of sorghum seeds. The same is true for composts based on Jatropha cakes.

\section{Total phenolics and total flavonoids contents of sorghum seeds}

The total phenolics and flavonoids contents of the sorghum of the different treatments are presented in Figures 4 and 5 respectively. The results show significant difference between treatments in the two parameters studied. Excepted the treatment G_S $(24.46 \pm 0.37 \mu \mathrm{g} \mathrm{GAE} / \mathrm{mg}$ of seeds) which obtained the highest total phenolics content, there were lower total phenolic contents in all other treatments compared to the control (22.40 $\pm 0.18 \mu \mathrm{g} \mathrm{GAE} / \mathrm{mg}$ of seeds). The lowest value was recorded with treatment $P_{-} S$ S $(17.62 \pm 0.33$ $\mu \mathrm{g}$ GAE/mg of seeds).

Concerning total flavonoids, treatments obtained by adding compost $+(\mathrm{G}+\mathrm{CP}, \mathrm{T}+\mathrm{CP}$ and $\mathrm{BM}+\mathrm{CP}$ ) showed the best contents compared to the control $(0.17 \pm 0.01 \mu \mathrm{g} \mathrm{QE} / \mathrm{mg}$ of seeds). The lowest values were recorded with treatment P_S $(0.09 \pm 0.01 \mu \mathrm{g}$ QE $/ \mathrm{mg})$ of seeds. $\mathrm{G}+\mathrm{CP}, \mathrm{T}+\mathrm{CP}$ and $\mathrm{BM}+\mathrm{CP}$ seeds had higher flavonoid levels than the control while the values recorded with the other treatments were lower than the control.

\section{Antioxidant activities of sorghum seeds}

The Ferric Reducing Antioxidant Power (FRAP) Assay of the seeds of the different treatments is presented in Figure 6. The results show a significant difference according to the treatments. The control treatment presented a high ability (1.66 $\pm 0.01 \mu \mathrm{g} \mathrm{AAE} / \mathrm{mg}$ of seeds) for ferric reducing compared to the other treatments, except for treatments G_S $(1.67 \pm$ $0.01 \mu \mathrm{g} \mathrm{AAE} / \mathrm{mg}$ of seeds) and BM+CP (1.69 $\pm 0.01 \mu \mathrm{g} \mathrm{AAE} / \mathrm{mg}$ of seeds), which have been more effective. The G_S and $\mathrm{BM}+\mathrm{CP}$ treatments were the only treatments with higher activity for ferric reducing activity power.

For DPPH Radical Scavenging Activity (Figure 7), only $\mathrm{BM}+\mathrm{CP}$ presented higher activity compared to the control. Other treatments did not improve the antioxidant activity of sorghum seeds in this test compared to control. 


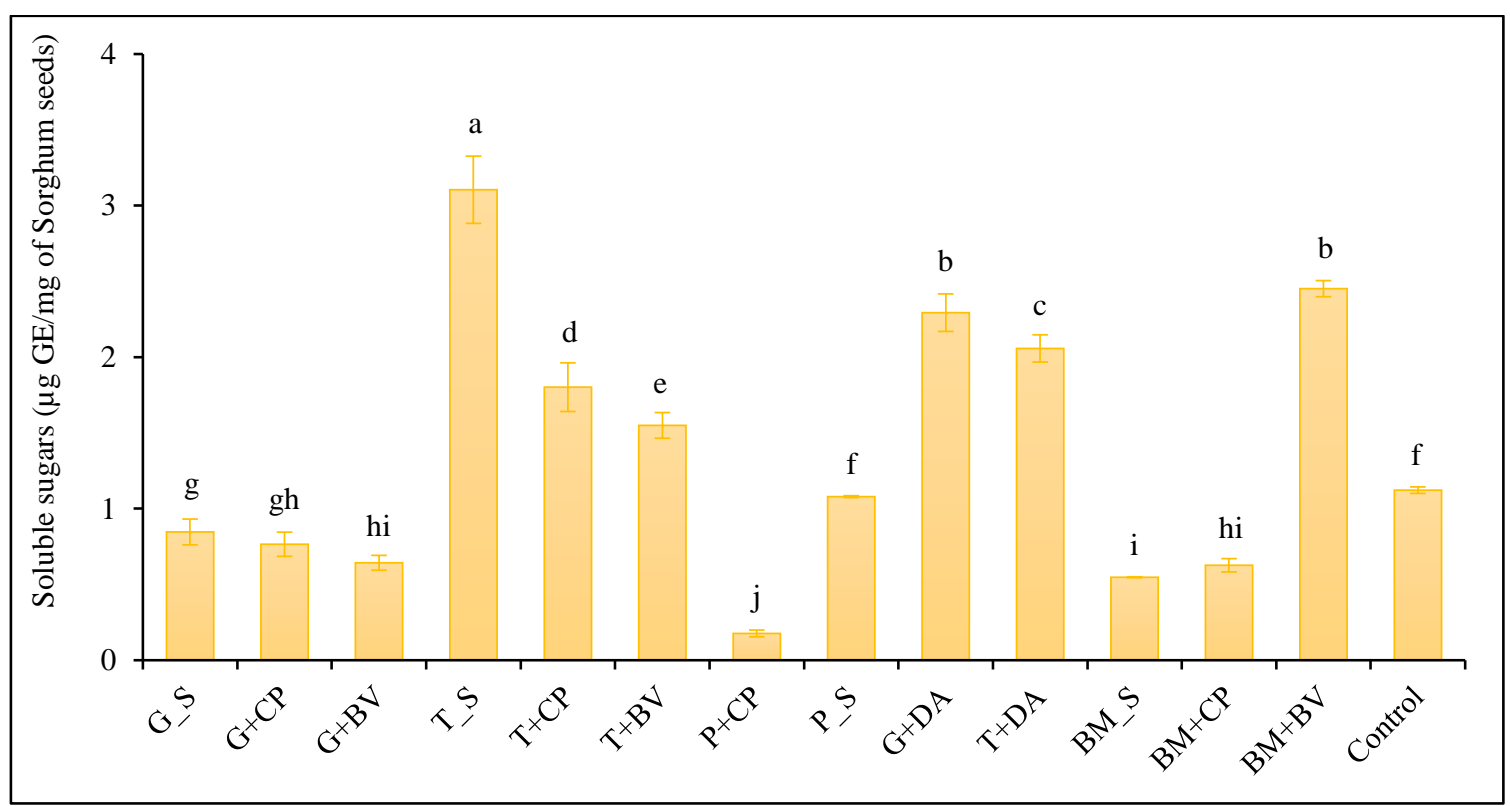

Values that have the same subscript are not significantly different according to the Newman-Keuls test at the 5\% level. Legend: G_S (Jatropha pod alone), G+CP (Jatropha pod + Compost+), G+BV (Jatropha pod + Cow dung), T_S (Jatropha cake alone), $\mathrm{T}+\mathrm{CP}($ Jatropha cake + Compost +$), \mathrm{T}+\mathrm{BV}$ (Jatropha cake + Crow dung), P+CP (Straw of sorghum + Compost+), P_S (Straw of sorghum alone), G+DA (Jatropha pod + Slaughterhouse waste), T+DA (Jatropha cake + Slaughterhouse waste), BM_S (Biomass of Jatropha alone), BM+CP (Biomass of Jatropha + Compost+), BM+BV (Biomass of Jatropha + Cow dung)

Figure 1: Carbohydrates contents.

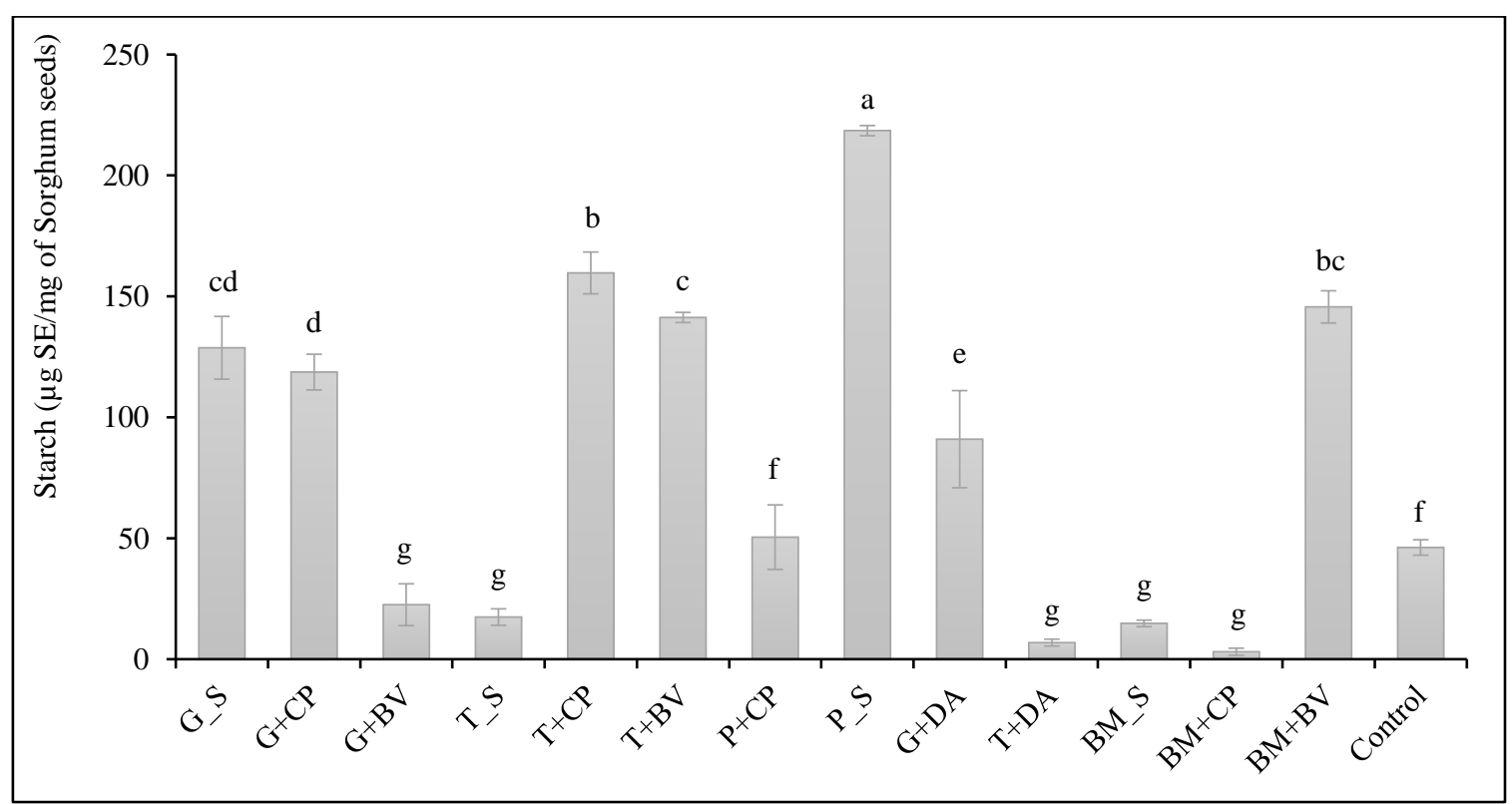

Values that have the same subscript are not significantly different according to the Newman-Keuls test at the 5\% level. Legend: G_S (Jatropha pod alone), G+CP (Jatropha pod + Compost+), G+BV (Jatropha pod + Cow dung), T_S (Jatropha cake alone), T+CP (Jatropha cake + Compost+), T+BV (Jatropha cake + Crow dung), P+CP (Straw of sorghum + Compost + ), P_S (Straw of sorghum alone), G+DA (Jatropha pod + Slaughterhouse waste), T+DA (Jatropha cake + Slaughterhouse waste), BM_S (Biomass of Jatropha alone), BM+CP (Biomass of Jatropha + Compost+), BM+BV (Biomass of Jatropha + Cow dung)

Figure 2: Starch contents. 

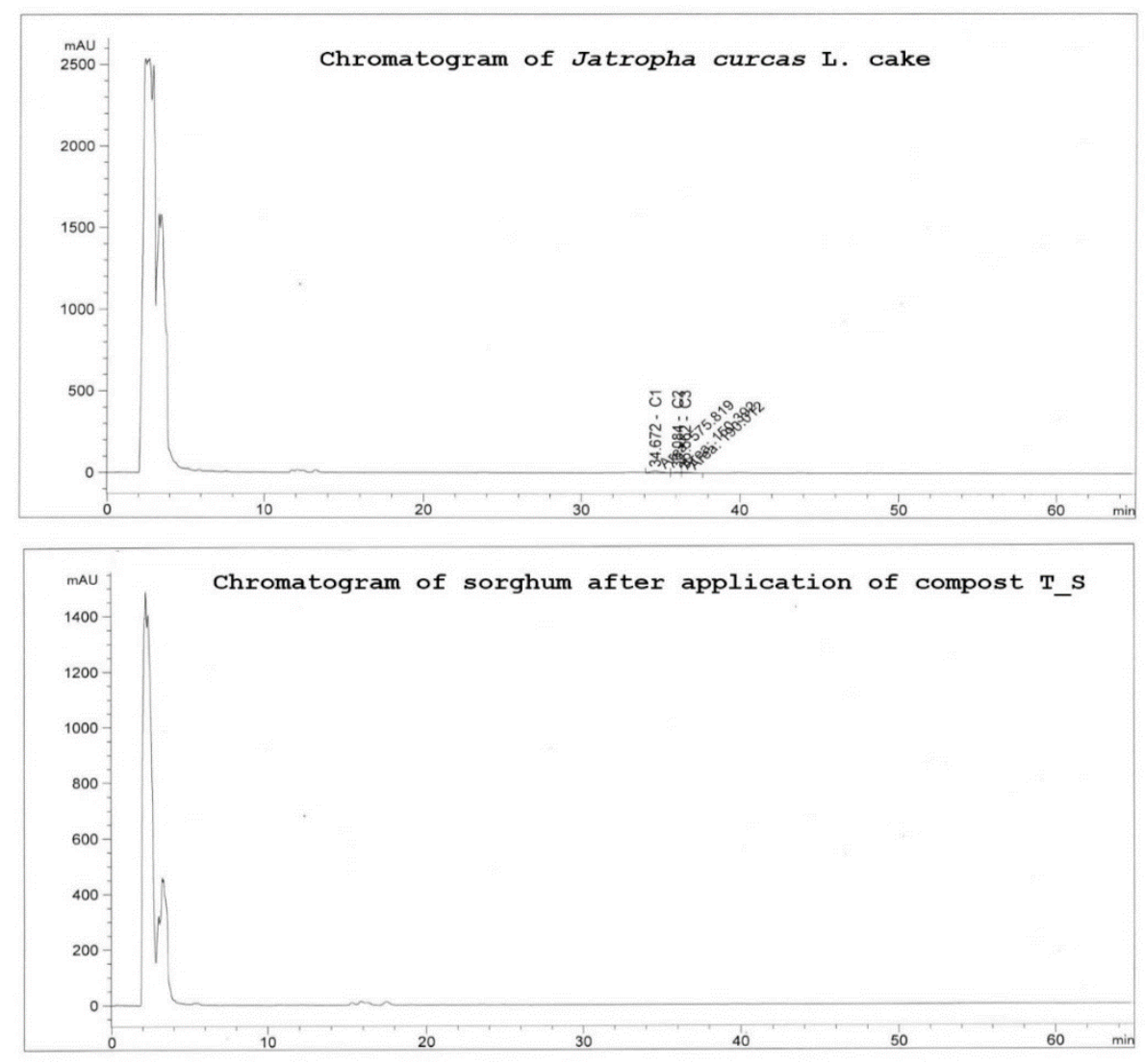

Figure 3: Chromatograms of the analysed samples.

Table 2: Matrix of presence/absence of phorbol esters.

\begin{tabular}{llcc}
\hline Treatments & \multicolumn{3}{c}{ Presence/Absence of phorbol esters } \\
\hline Determined phorbol esters & C1 & C2 & C3 \\
\hline$J C L$ cake (positive control) & + & + & + \\
Compost based on JCL cake & - & - & - \\
G_S & - & - & - \\
G+CP & - & - & - \\
G+BV & - & - & - \\
T_S & - & - & - \\
T+CP & - & - & - \\
T+BV & - & - & - \\
P+CP & - & - & - \\
P_S & - & - & - \\
G+DA & - & - & - \\
T+DA & - & - & - \\
BM_S & - & - & - \\
BM+CP & - & - & - \\
BM+BV & - & - & - \\
Control & - & - & - \\
\hline
\end{tabular}

Legend :(+) or (-) mean presence or absence of phorbol esters; C1, C2 and C3: characterised forms of phorbol esters 


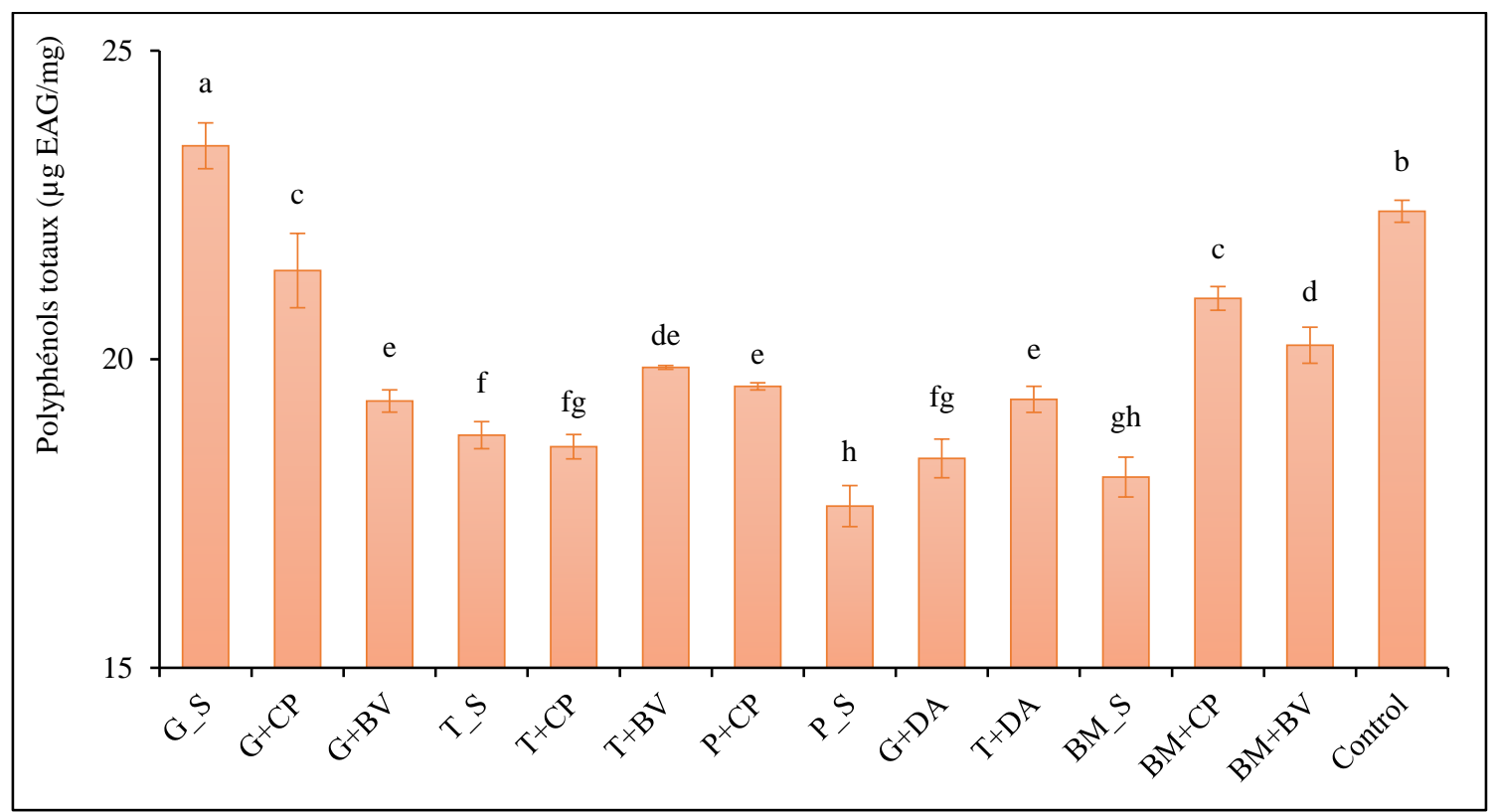

Values that have the same subscript are not significantly different according to the Newman-Keuls test at the 5\% level. Legend: G_S (Jatropha pod alone), G+CP (Jatropha pod + Compost+), G+BV (Jatropha pod + Cow dung), T_S (Jatropha cake alone), T+CP (Jatropha cake + Compost + ), T+BV (Jatropha cake + Crow dung), P+CP (Straw of sorghum + Compost + ), P_S (Straw of sorghum alone), G+DA (Jatropha pod + Slaughterhouse waste), T+DA (Jatropha cake + Slaughterhouse waste), BM_S (Biomass of Jatropha alone), BM+CP (Biomass of Jatropha + Compost+), BM+BV (Biomass of Jatropha + Cow dung)

Figure 4: Total phenolics content.

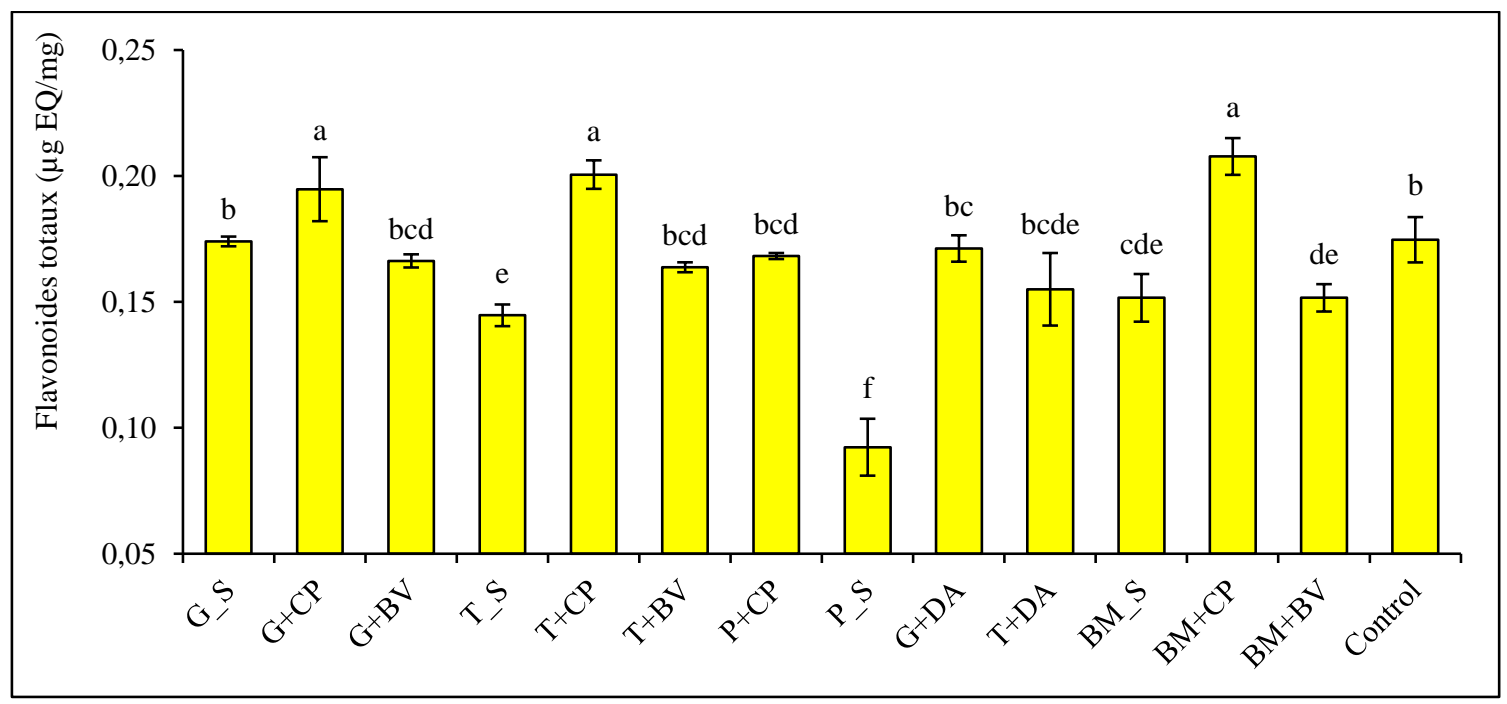

Values that have the same subscript are not significantly different according to the Newman-Keuls test at the 5\% level. Legend: G_S (Jatropha pod alone), G+CP (Jatropha pod + Compost+), G+BV (Jatropha pod + Cow dung), T_S (Jatropha cake alone), T+CP (Jatropha cake + Compost+), T+BV (Jatropha cake + Crow dung), P+CP (Straw of sorghum + Compost + ), P_S (Straw of sorghum alone), G+DA (Jatropha pod + Slaughterhouse waste), T+DA (Jatropha cake + Slaughterhouse waste), BM_S (Biomass of Jatropha alone), BM+CP (Biomass of Jatropha + Compost+), BM+BV (Biomass of Jatropha + Cow dung)

Figure 5: Total flavonoids content. 


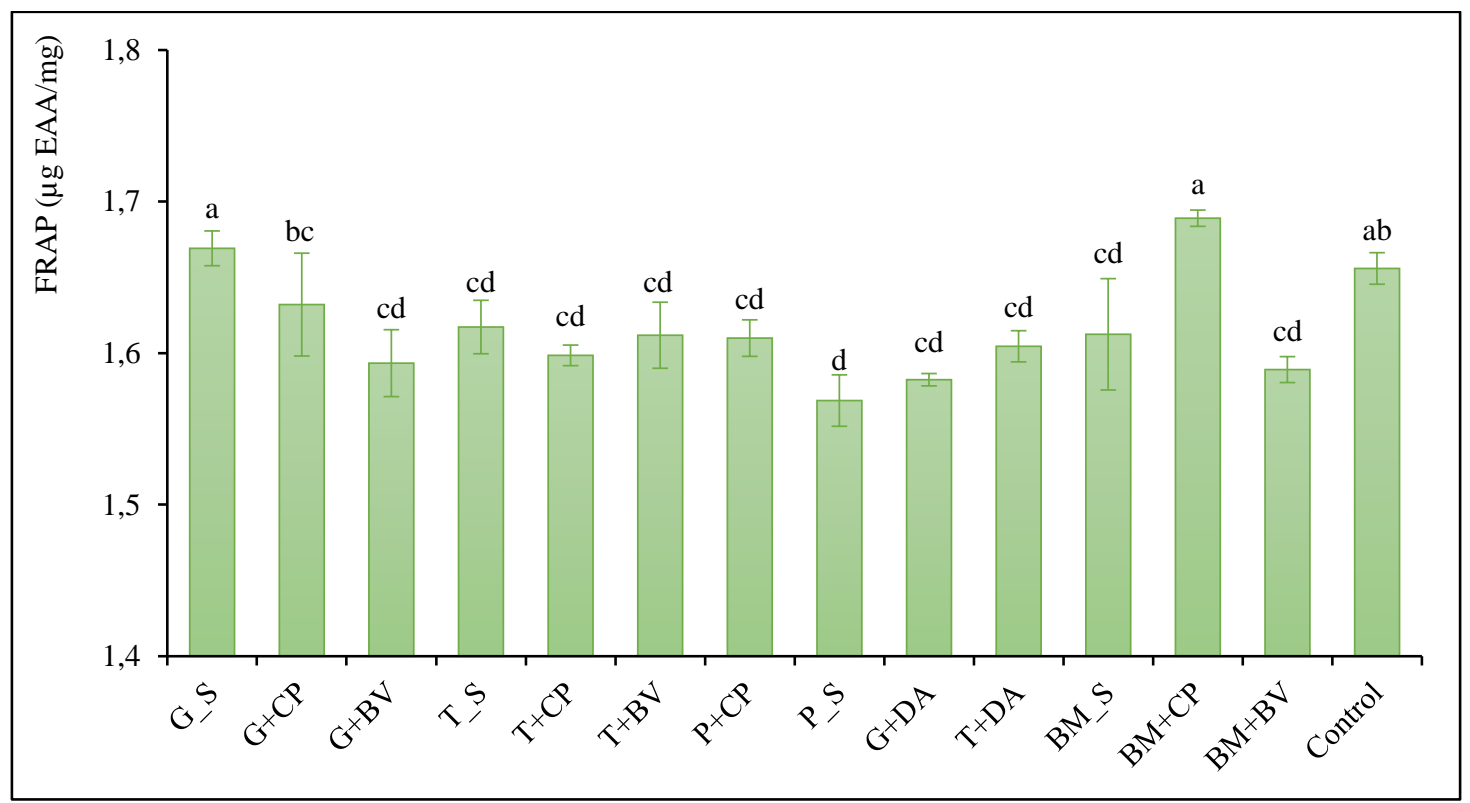

Values that have the same subscript are not significantly different according to the Newman-Keuls test at the 5\% level. Legend: G_S (Jatropha pod alone), G+CP (Jatropha pod + Compost+), G+BV (Jatropha pod + Cow dung), T_S (Jatropha cake alone), $\mathrm{T}+\mathrm{CP}($ Jatropha cake + Compost +$), \mathrm{T}+\mathrm{BV}$ (Jatropha cake + Crow dung), P+CP (Straw of sorghum + Compost+), P_S (Straw of sorghum alone), G+DA (Jatropha pod + Slaughterhouse waste), T+DA (Jatropha cake + Slaughterhouse waste), BM_S (Biomass of Jatropha alone), BM+CP (Biomass of Jatropha + Compost+), BM+BV (Biomass of Jatropha + Cow dung)

Figure 6: Ferric Reducing Antioxidant Power (FRAP) Assay.

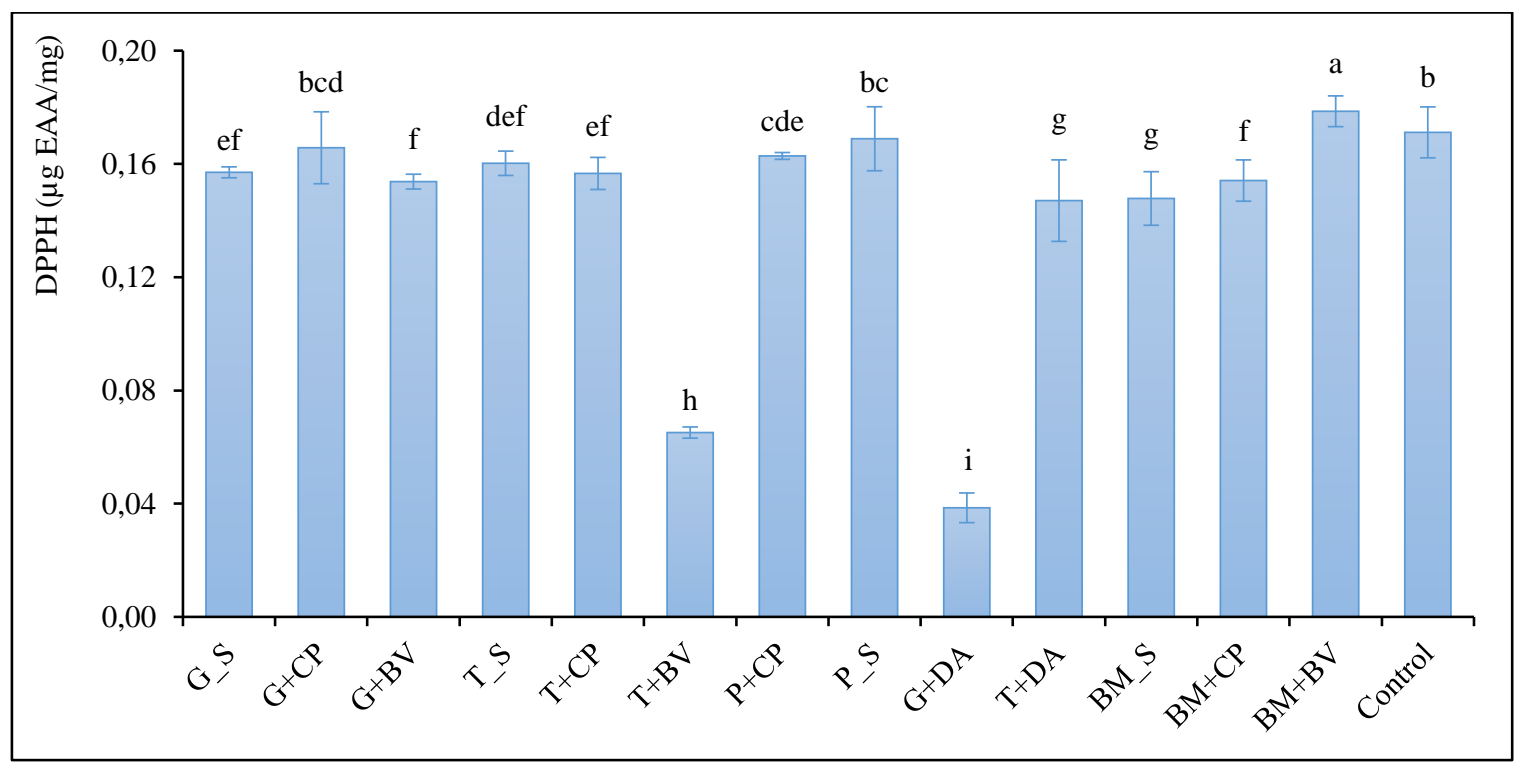

Values that have the same subscript are not significantly different according to the Newman-Keuls test at the 5\% level. Legend: G_S (Jatropha pod alone), G+CP (Jatropha pod + Compost+), G+BV (Jatropha pod + Cow dung), T_S (Jatropha cake alone), T+CP (Jatropha cake + Compost+), T+BV (Jatropha cake + Crow dung), P+CP (Straw of sorghum + Compost+), P_S (Straw of sorghum alone), G+DA (Jatropha pod + Slaughterhouse waste), T+DA (Jatropha cake + Slaughterhouse waste), BM_S (Biomass of Jatropha alone), BM+CP (Biomass of Jatropha + Compost+), BM+BV (Biomass of Jatropha + Cow dung)

Figure 7: DPPH Radical Scavenging Activity. 


\section{DISCUSSION}

\section{Carbohydrates and starch contents of sorghum seeds}

Carbohydrate and starch contents in sorghum seeds were significantly higher with the application of some of the applied compost compared to the control. However, some of the applied compost showed decreases in the parameters evaluated compared to control. The improvement in the content of the chemical compounds indicates the beneficial role of the compost in improving the content of these interest compounds (Geng et al., 2019; Palansooriya et al., 2020). The highest carbohydrate contents were produced in plants treated by compost based on Jatropha cake alone. These results could be supported by the Carbon/Nitrogen balance hypothesis. When nitrogen is quickly available, plants trend primarily to make high nitrogen-content containing compounds (for example, proteins for growth) (Sarwar et al., 2019). But, when nitrogen availability is reduced, plants would make more carbon-containing compounds such as carbohydrates, starch and cellulose (Horner et al., 1988).

\section{Phorbol esters contents of sorghum seeds}

The absence of phorbol esters in composts and sorghum seeds could be explained by their degradation by microbial organisms during the composting process. Phorbol esters are completely biodegraded by certain microorganisms, soil moisture and temperature (Devappa et al., 2010). This corroborates other reports that there is no risk of crop contamination by phorbol esters (Nesseim, 2017). This study revealed that a biological treatment combined with heat treatment was able to degrade phorbol esters.

\section{Total phenolics and total flavonoids contents of sorghum seeds}

Phenolic and flavonoid contents were affected by the different compost in this study. The phenolic contents of seeds are linked to environmental conditions (Salazar-López et al., 2018). The application of some compost increased the production of phenolics and flavonoids contents (Lakhdar et al., 2011;
Giménez et al., 2020). The availability of nitrogen should influence the amounts of phenolics more strongly than terpenoids because phenolics are produced in the same shikimic acid pathway as aromatic amino acids as suggested previously. Therefore, it can be suggested that the concentration phenolics in plants are decreased at high nitrogen availability and vice versa. The reductions in the flavonoids and total phenolic contents observed could be attributed to the competition for phenylalanine which is either used to synthesize phenolic compounds or some others compounds such as proteins (Olarewaju et al., 2018). As protein accumulates due to higher concentration of nitrogen, the level of phenolic compounds is reduced for a certain amount of phenylalanine (Kováčik et al., 2007; Elhanafi et al., 2019).

\section{Antioxidant activities of sorghum seeds}

The different treatments did not improve the antioxidant activities of sorghum seeds. Indeed, apart from the treatments G_S and $\mathrm{BM}+\mathrm{CP}$ for ferric reducing ability and $\mathrm{BM}+\mathrm{CP}$ for DPPH radical scavenging assay, which presented statistical high activities from control, the other treatments presented generally low or identical antioxidant activities from the control. That means that in this study there was no contribution of the different compost in improving the sorghum antioxidants activities. The findings are in contrast with Sarwar et al. (2019) that reported the application of organic manure (compost) increased the radical scavenging activity in Moringa oleifera but reduced significantly by the application of inorganic fertilizer. The usage of compost could enhance the production of secondary metabolites and improve antioxidant activities (DPPH and FRAP) of Labisia pumila herb (Ibrahim et al., 2013). This may be due to the difference in plants species, type of fertilizer, the origin of the compost applied and the local environmental stresses (biotic or abiotic).

\section{Correlations}

The matrix showing the correlations between chemical compounds and antioxidant 
activities of sorghum seeds are presented in Table 3. The results showed that the ferric reducing ability power was significantly and positively correlated to the total phenolics content $(r=0.792)$ and flavonoids $(r=0.602)$ content. The analysis of the main components (Figure 8) has enabled the various treatments to be divided into 4 groups. Group 1 includes, in addition to the control treatment, the treatments G_S, G+CP and P+CP. Group 2 consists of the treatments G+BV, P_S, BM_S and BM+BV. The treatments $\mathrm{T} \_\mathrm{S}, \mathrm{T}+\mathrm{CP}, \mathrm{T}+\mathrm{BV}, \mathrm{G}+\mathrm{DA}$, $\mathrm{T}+\mathrm{DA}$ constitute the group 3 while the treatment $\mathrm{BM}+\mathrm{CP}$ constitutes the 4th group. The biplot (axes $F_{1}$ and $F_{2}: 63 \%$ ) shows that the flavonoid content and the reducing power of iron 3 are closely related to the $\mathrm{BM}+\mathrm{CP}$ treatment. Also, the treatments of the control group improved the total polyphenol content and the DDPH activity. Group 2 and 3 treatments improved the starch and carbohydrate content respectively.

Similar results were reported in the work on effect of organic and NPK Fertilizers on biochemical components and antioxidant properties of Cowpea (Vigna unguiculata $\mathrm{L}$. Walp.), revealed correlations between some evaluated parameters and also distinguished different group of fertilizers with different characteristics (Sombié et al., 2019). Treatment with Group I fertilizers strongly improved lycopene, $\beta$-carotene and total chlorophyll contents, height and number of branches. Which of Group II were highly linked to FRAP and DPPH activities and protein content, while fertilizers of Group III strongly improved to salicylic, soluble sugar, phenolics and flavonoids contents and trypsin inhibition activities.

Table 3: Matrix of correlations of the different measured parameters.

\begin{tabular}{|c|c|c|c|c|c|c|}
\hline Variables & $\begin{array}{c}\text { Carbohydrates } \\
(\mu \mathrm{g} \text { EG/mg) }\end{array}$ & $\begin{array}{c}\text { Starch } \\
(\mu \mathrm{g} \\
\text { SE } / \mathbf{m g}) \\
\end{array}$ & $\begin{array}{c}\text { Total } \\
\text { phenolics }(\mu \mathrm{g} \\
\text { GAE } / \mathbf{m g}) \\
\end{array}$ & $\begin{array}{c}\text { Total } \\
\text { flavonoids } \\
(\mu \mathrm{g} \mathrm{QE} / \mathrm{mg}) \\
\end{array}$ & $\begin{array}{c}\text { FRAP } \\
(\mu \mathrm{g} \\
\text { AAE/mg }) \\
\end{array}$ & $\begin{array}{c}\text { DPPH } \\
(\mu \mathrm{g} \\
\text { AAE/mg })\end{array}$ \\
\hline $\begin{array}{l}\text { Carbohydrates } \\
\text { ( } \mu \mathrm{g} \text { EG/mg) }\end{array}$ & 1 & & & & & \\
\hline $\begin{array}{l}\text { Starch } \\
(\mu \mathrm{g} \mathrm{SE} / \mathrm{mg})\end{array}$ & 0.097 & 1 & & & & \\
\hline $\begin{array}{l}\text { Total phenolics } \\
\text { ( } \mu \text { g GE/mg) }\end{array}$ & -0.274 & -0.052 & 1 & & & \\
\hline $\begin{array}{l}\text { Total flavonoids } \\
\text { ( } \mu \mathrm{g} \text { QE/mg) }\end{array}$ & -0.206 & -0.294 & 0.492 & 1 & & \\
\hline $\begin{array}{l}\text { FRAP } \\
(\mu \mathrm{g} \text { AAE/mg) }\end{array}$ & -0.354 & -0.380 & 0.792 & 0.602 & 1 & \\
\hline $\begin{array}{l}\text { DPPH } \\
(\mu \mathrm{g} \text { AAE/mg) }\end{array}$ & -0.246 & -0.058 & 0.246 & -0.085 & 0.224 & 1 \\
\hline
\end{tabular}

Values in bold are significance different at alpha $=0.05$

Legend: FRAP (Ferric Reducing Antioxidant Power), DPPH (2,2-diphenyl-1-picrylhydrazyl), GAE (Gallic Acid Equivalent),

QE (Quercetin Equivalent), AAE (Ascorbic Acid Equivalent), GE (Glucose Equivalent), SE (Starch EquiValent) 


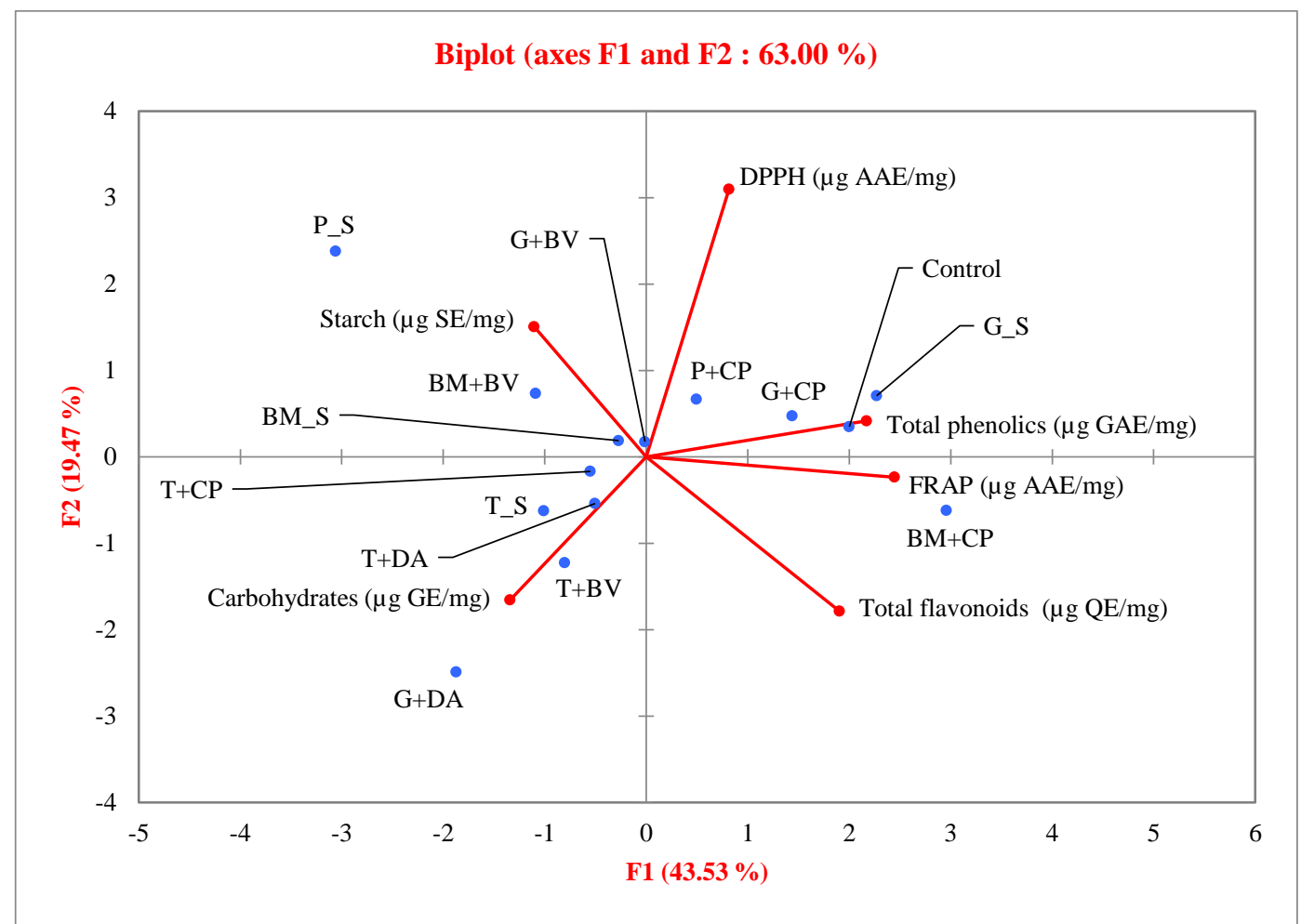

Legend: G_S (Jatropha pod alone), G+CP (Jatropha pod + Compost+), G+BV (Jatropha pod + Cow dung), T_S (Jatropha cake alone), T+CP (Jatropha cake + Compost+), T+BV (Jatropha cake + Crow dung), P+CP (Straw of sorghum + Compost+), P_S (Straw of sorghum alone), G+DA (Jatropha pod + Slaughterhouse waste), T+DA (Jatropha cake + Slaughterhouse waste), BM_S (Biomass of Jatropha alone), BM+CP (Biomass of Jatropha + Compost+), BM+BV (Biomass of Jatropha + Cow dung)

Figure 8: Principal components analysis of the different evaluated parameters.

\section{Conclusion}

This study evaluated the nutraceutical properties of sorghum seeds by application of various compost-based by-products of Jatropha curcas. The results have showed positive and significant correlations between ferric reduction ability and total phenolics on one hand and total flavonoids on the other. The correlations between these different parameters are important for simultaneously improvement biochemical and phytochemical parameters of sorghum seeds. Principle components analyses allowed classification of the different treatments into 4 groups, each group being specific for improving the content of biochemical molecules and/or antioxidant activity in sorghum seeds.

\section{COMPETING INTERESTS}

All authors agree with the content of the manuscript. They declare no competing interest regarding the publication of this article.

\section{AUTHORS' CONTRIBUTIONS}

The protocol and experimental set-up were written and implemented by AND, BY and $\mathrm{AH}$. The analysis and drafting of the manuscript were done by AND and HS. The revision of the manuscript was done by all coauthors.

\section{ACKNOWLEDGEMENTS}

The authors are grateful to the African Union for financial support through the AUJatropha Project and to INERA and LNSP for technical support. 


\section{REFERENCES}

Akinseye FM, Adam M, Agele SO, Hoffmann MP, Traore PCS, Whitbread AM. 2017. Assessing crop model improvements through comparison of sorghum (Sorghum bicolor L. moench) simulation models: A case study of West African varieties. Field Crops Research, 201: 19-31. DOI: 10.1016/j.fcr.2016.10.015.

Asif M, Muneer T. 2007. Energy supply, its demand and security issues for developed and emerging economies. Renewable and Sustainable Energy Reviews, 11(7): 1388-1413. DOI: 10.1016/j.rser.2005.12.004.

Bationo A, Kihara J, Vanlauwe B, Waswa B, Kimetu J. 2007. Soil organic carbon dynamics, functions and management in West African agro-ecosystems. Agricultural Systems, 94(1): 13-25. DOI: 10.1016/j.agsy.2005.08.011.

Bazongo P, Traoré K, Sanon KB, Yélémou B, Traoré O, Nacro BH, Bacye B, Belem M, Traoré M, Hien V, Sedego MP. 2015. Impact of Jatropha plantation on soil chemical and biological properties in the South Sudanian region in Burkina Faso. International Journal of Biological and Chemical Sciences, 9(4): 1762-1778. DOI: 10.4314/ijbcs.v9i4.3.

Cao X, Dai X, Liu J. 2016. Building energyconsumption status worldwide and the state-of-the-art technologies for zeroenergy buildings during the past decade. Energy and Buildings, 128: 198-213. DOI: 10.1016/j.enbuild.2016.06.089.

Das N, Chandran P. 2011. Microbial Degradation of Petroleum Hydrocarbon Contaminants: An Overview. Biotechnology Research International, 2011: 1-13. DOI: 10.4061/2011/941810.

Derra A-N, Yélémou B, Sanon KB, Hilou A, Millogo-Rasolodimby J, Hien V. 2013. Management patterns of Jatropha curcas: impact on the microbial and the mycorrhizial biomasses in different phyto-geographic zones of Burkina Faso. Advances in Applied Science Research, 256-267. Available at: http://www.pelagiaresearchlibrary.com/ advances-in-applied-science/vol4iss6/AASR-20130-4-6-256-267.pdf.

Devappa RK, Makkar HPS, Becker K. 2010. Biodegradation of Jatropha curcas phorbol esters in soil. Journal of the Science of Food and Agriculture, 90(12): 2090-2097. DOI: 10.1002/jsfa.4056.

Dubois M, Gilles KA, Hamilton JK, Rebers PA, Smith F. 1956. Colorimetric method for determination of sugars and related substances. Analytical Chemistry, 28(3): 350-356. DOI: 10.1021/ac60111a017.

Elhanafi L, Houhou M, Rais C, Mansouri I, Elghadraoui L, Greche H. 2019. Impact of Excessive Nitrogen Fertilization on the Biochemical Quality, Phenolic Compounds and Antioxidant Power of Sesamum indicum L Seeds. Journal of Food Quality, 2019: 1-6. DOI: 10.1155/2019/9428092.

Firdaus MS, Husni MHA. 2012. Planting Jatropha curcas on constrained land: Emission and effects from land use change. The Scientific World Journal, 2012: 1-7. DOI: $10.1100 / 2012 / 405084$.

Geng Y, Cao G, Wang L, Wang S. 2019. Effects of equal chemical fertilizer substitutions with organic manure on yield, dry matter, and nitrogen uptake of spring maize and soil nitrogen distribution. PLoS ONE, 14(7): 1-16. DOI: 10.1371/journal.pone.0219512.

Giménez A, Fernandez JA, Pascual JA, Ros M, Egea-Gilabert C. 2020. Application of Directly Brewed Compost Extract Improves Yield and Quality in Baby Leaf Lettuce Grown Hydroponically. Agronomy Journal, 370(10): 1-15.

Hanff E, Dabat M-H, Blin J. 2011. Are biofuels an efficient technology for generating sustainable development in oil-dependent African nations? A macroeconomic assessment of the opportunities and impacts in Burkina Faso. Renewable and Sustainable Energy Reviews, 15(5): 2199-2209. DOI: 10.1016/j.rser.2011.01.014.

Horner JD, Gosz JR, Cates RG. 1988. The role of carbon-based plant secondary metabolites in decomposition in 
terrestrial ecosystems. Chicago Journals, 132(6): 869-883. DOI: 10.1007/978-3-642-61320-3_6.

Ibrahim MH, Jaafar HZE, Karimi E, Ghasemzadeh A. 2013. Impact of organic and inorganic fertilizers application on the phytochemical and antioxidant activity of Kacip Fatimah (Labisia pumila Benth). Molecules, 18(9): $\quad$ 10973-10988. DOI: 10.3390/molecules 180910973.

Janin P, Ouédraogo F-C. 2009. Enjeux des agrocarburants au Burkina Faso : le cas du Jatropha curcas L. IRD : Paris.

Jarvis CE, Walker JRL. 1993. Simultaneous, rapid, spectrophotometric determination of total starch, amylose and amylopectin. Journal of the Science of Food and Agriculture, 63: 53-57. DOI: $10.1002 /$ jsfa.2740630109.

Joshi R, Singh J, Vig AP. 2014. Vermicompost as an effective organic fertilizer and biocontrol agent: effect on growth, yield and quality of plants. Reviews in Environmental Science and Biotechnology, 14(1): 137-159. DOI: 10.1007/s11157-014-9347-1.

Kenga R, Alabi SO, Gupta SC. 2004 Combining ability studies in tropical sorghum (Sorghum bicolor (L.) Moench). Field Crops Research, 88(1): 251-260.

DOI: 10.1016/j.fcr.2004.01.002.

Makkar HPS, Becker K, Sporer F, Wink M. 1997. Studies on Nutritive Potential and Toxic Constituents of Different Provenances of Jatropha curcas. Journal of Agricultural and Food Chemistry, 45(8): 3152-3157. DOI: 10.1021/jf970036j.

Mirza MMQ. 2003. Climate change and extreme weather events: Can developing countries adapt? Climate Policy, 3(3): 233-248. DOI: 10.3763/cpol.2003.0330.

N'Dayegamiye A, Drapeau ARLM. 2005. Effets des apports de composts de résidus ménagers sur les rendements des cultures et certaines propriétés du sol. Agrosolutions, 16(2): 135-144.
Nesseim TDT. 2017. Valorisation des sousproduits de la graine de Jatropha curcas L. en production de poulets au Sénégal. Université de Liège.

Olarewaju OA, Alashi AM, Aluko R E. 2018. Antihypertensive effect of aqueous polyphenol extracts of Amaranthusviridis and Telfairiaoccidentalis leaves in spontaneously hypertensive rats. Journal of Food Bioactives, 1: 166-173. DOI: 10.31665/jfb.2018.1135.

Ouédraogo E, Mando A, Zombré NP. 2001. Use of compost to improve soil properties and crop productivity under low input agricultural system in West Africa. Agriculture, Ecosystems and Environment, 84(3): 259-266. DOI: 10.1016/S0167-8809(00)00246-2.

Palansooriya KN, Shaheen SM, Chen SS, Tsang DCW, Hashimoto Y, Hou D, Bolan NS, Rinklebe J, Ok YS. 2020. Soil amendments for immobilization of potentially toxic elements in contaminated soils: A critical review. Environment International, 134: 105046-105075. DOI: 10.1016/j.envint.2019.105046.

Salazar-López NJ, González-Aguilar GA, Rouzaud-Sández O, Robles-Sánchez M. 2018. Bioaccessibility of hydroxycinnamic acids and antioxidant capacity from sorghum bran thermally processed during simulated in vitro gastrointestinal digestion. Journal of Food Science and Technology, 55(6): 2021-2030. DOI: 10.1007/s13197-0183116-z.

Sama H, Ouattara B, Hilou A, Derra A-N, Hien V. 2018. Variability of morphometric traits and oleaginous biofuel potential of Jatropha curcas L. (Euphorbiaceae) seeds in Burkina Faso. African Journal of Agricultural Research, 13(52): 2911-2918. DOI: 10.5897/AJAR2018.13196.

Sarwar M, Patra JK, Ali A, Maqbool M, Arshad MI. 2019. Effect of compost and NPK fertilizer on improving biochemical and antioxidant properties 
of Moringa oleifera. South African Journal of Botany, 129: 62-66. DOI: 10.1016/j.sajb.2019.01.009.

Shuaibu YM, Fagam AS, Kawure S. 2018. Effects of poultry manure based compost and NPK fertilizer on the growth and yield of sorghum (Sorghum bicolor L. moench) in Bauchi State, Nigeria. GSC Biological and Pharmaceutical Sciences, 2(1): 016-024.

Sombié PAED, Hilou A, Mounier C, Coulibaly AY, Kiendrebeogo M, Millogo JF, Nacoulma OG. 2011. Antioxidant and anti-infammatory activities from galls of Guiera senegalensis J. F. Gmel (Combretaceae). Research Journal of Medicinal Plant, 5(4): 448-461.

Sombié PAED, Sama H, Sidibé H, Kiendrébéogo M. 2019. Effect of Organic (Jatropha Cake) and NPK Fertilizers on Improving Biochemical
Components and Antioxidant Properties of Five Cowpea (Vigna unguiculata L. Walp.) Genotypes. Journal of Agricultural Science, 11(10): p.48. DOI: 10.5539/jas.v11n10p48.

Somda BB, Ouattara B, Serme I, Pouya MB, Lompo F, Taonda SJB, Sedogo PM. 2017. Détermination des doses optimales de fumures organo-minérales en microdose dans la zone soudanosahélienne du Burkina Faso. International Journal of Biological and Chemical Sciences, 11(2): 670-683. DOI: 10.4314/ijbcs.v11i2.11.

Traoré M, Nacro HB, Doamba WK, Tabo R, Nikiema A. 2015 Effets de doses variées du tourteau de Jatropha curcas sur la productivité du mil (variété HKP) en condition pluviale en Afrique de l'Ouest. Tropicultura, 33(1): 19-25. 